\title{
Lack of stable inheritance of introgressed transgene from oilseed rape in wild radish
}

\author{
Anoir AL MOUEMAR ${ }^{1}$ and Henri DARMENCY* \\ Unité Mixte de Recherche sur la Biologie et la Gestion des Adventices, INRA, BP 86510, 21065 Dijon, France \\ ${ }^{1}$ Department of Plant Protection, Faculty of Agronomy, Damas University, Syria
}

Hybridization of Brassica napus L. (oilseed rape) and Raphanus raphanistrum L. (wild radish) has been demonstrated, and may be the first step towards introgression of transgenes in this wild relative. If wild radish were to display a new adaptive advantage by expressing the transgene, this could modify the ecological balance of species within the agro-ecosystem. To determine if transgenes remained stable in the hybrid, the frequency of herbicide resistance was studied over four advanced generations of hybrid progeny (G8 to G11) that were subjected to herbicide selection pressure. It is expected that hemizygous resistant plants containing an herbicide resistance transgene back-crossed to wild radish would have $50 \%$ resistant progeny. In each of the G8 to G11 generations, only $18 \%$ of the progeny from resistant plants were resistant. The chromosome complement of herbicide-susceptible progenies, analyzed at G9, was not different from that of wild populations of wild radish. Herbicide-resistant G9 progeny showed higher chromosome instability, and one third of the progeny contained a supernumerary chromosome. These results suggest that in the presence of herbicide selection pressure, the transgene for herbicide resistance would be maintained despite a lack of stabilized introgression. In the absence of selection, the frequency of resistance in the population is expected to decline.

Keywords: transgene / herbicide resistance / inheritance / hybridization / introgression / chromosome / Brassica napus / Raphanus raphanistrum

\section{INTRODUCTION}

There is wide public concern about hybridization and introgression of trangenes from genetically modified crops into wild species, which may possibly create more invasive or pervasive weed biotypes, or modify the ecological balance of species within the agro-ecosystem (Ellstrand et al., 1999; Stewart et al., 2003). The longterm consequences of the release of transgenic crops have yet to be determined. Gene flow from transgenic Brassica napus L., oilseed rape, is of particular concern, as this species is grown widely in the presence of weedy wild relatives with which it can outcross. Spontaneous hybrids were identified between oilseed rape $(2 n=38)$ and the widespread weed Raphanus raphanistrum $\mathrm{L}$. $(2 n=18)$, wild radish. Although only four such hybrids have been reported with wild radish as the female parent (Chèvre et al., 2000; Darmency et al., 1998; Warwick et al., 2003), more can be generated through reciprocal crosses (Baranger et al., 1995; Chèvre et al., 2000; Darmency et al., 1998; Eber et al., 1994; Rieger et al., 2001). Hybrids were very infertile but produced a few progeny with restored fertility (Benabdelmouna et al., 2003; Chèvre et al., 1997a, 1998, 1999; Darmency et al., 1998; Guéritaine et al., 2003). However, whether the enhanced fitness value conferred by the transgene could alter the behavior of the wild species depends on the likelihood of stable genomic introgression. Here we study the herbicide resistance trait in hybrid derivatives obtained from an initial cross by Baranger et al. (1995) between a transgenic line of B. napus (from Bayer Crop Science), with resistance to the herbicide glufosinate conferred by the bar gene (De Block et al., 1989), and wild radish. While herbicide-resistant descendants from such a cross were present in first and second backcross generations, those with a normal wild radish

\footnotetext{
* Corresponding author: Darmency@ dijon.inra.fr
} 
Table 1. Percentage of herbicide-resistant progeny in four successive generations (G8 to G11).

\begin{tabular}{lccccc}
\hline \hline Generation $^{1}$ & $\begin{array}{c}\text { No. of } \\
\text { Plants }^{2}\end{array}$ & $\begin{array}{c}\text { No. of } \\
\text { seedlings }^{3}\end{array}$ & $\begin{array}{c}\text { Mean \% } \\
\text { resistance }(\%)^{4}\end{array}$ & Range & $\chi^{2}$ \\
\hline G8 & 17 & 2204 & $19.3(1.0)$ a & $9-27$ & 14.6 NS \\
G9 & 17 & 1101 & $22.4(2.0) \mathrm{a}$ & $7-43$ & $27.2 *$ \\
G10 & 11 & 884 & $16.2(3.3)$ ab & $0-43$ & $69.2 * * *$ \\
G11 & 20 & 1764 & $12.7(1.1) \mathrm{b}$ & $4-20$ & $35.4 *$ \\
G11bis & 21 & 1628 & $19.5(1.8) \mathrm{a}$ & $0-37$ & $60.8 * * *$ \\
\hline
\end{tabular}

${ }_{1}^{1}$ : G11bis was produced in a separate cage by plants issued from only one G10 family having high resistance frequency, in order to intentionally increase the resistance rate in the next generation. ${ }^{2}$ : number of glufosinate-resistant plants. ${ }^{3}$ : total number of seedlings tested, mean percentage of resistant seedlings (and S.E.), range of variation and test of heterogeneity within generation. ${ }^{4}:$ mean values followed by the same letter within a column are not different at $P=0.05$ (Bonferroni adjustment of ANOVA). NS, *, ***: $\chi^{2}$ homogeneity test among plants not significant, significant at $P=0.05$ and 0.001 , respectively.

chromosome number did not carry the herbicide resistance trait, indicating that no genomic introgression had occurred (Chèvre et al., 1998; Guéritaine et al., 2002). Backcrossing resistant plants to wild radish was continued up to the BC7 generation. Subsequent generations of hybrid progeny G8 to G11 were grown under random mating and selection pressure from the herbicide to simulate cultivated field conditions. We show that only $18 \%$ of the progeny from resistant plants from these advanced generations were resistant, and unlike susceptible progeny from the same families, showed higher chromosome instability.

\section{RESULTS AND DISCUSSION}

\section{The resistance trait}

None of the plants showed normal Mendelian segregation. It was expected that hemizygous resistant plants containing herbicide-resistance transgenes back-crossed to wild radish would have $50 \%$ resistant progeny, and more if the pollinator also segregated for resistance. The percentage of resistant progeny in each seedling family varied widely, ranging from 0 to $43 \%$ (Tab. 1). One G9 family had a significantly higher percentage than the others ( $43 \%$ versus a range of 7 to $31 \%$ ), and again at G10 ( $43 \%$ versus a range of 0 to $22 \% ; \chi^{2}$ test, Tab. 1). Plants from the latter G10 family were placed in a separate cage in order to intentionally increase the resistance rate in the next generation (G11bis in Tab. 1), but only two of the G11bis families examined had a value higher than $34 \%$, and the resulting mean score was only $19.5 \%$. In general, there was no significant correlation between scores of mother plants and their descendants $(r=-0.08$, NS at $P=$ 0.05 with $36 \mathrm{df}$ ). For instance, the G10 progeny with $0 \%$ resistance originated from one resistant plant of a G9 family with $43 \%$ resistance. On average, the percentage of resistant seedlings in the G8 to G10 generations was $19.3 \%$, but decreased to $12.7 \%$ at G11 (Tab. 1). This decrease could be biased, due to a low fecundity rate at G10. Inclusion of the G11bis set of plants with other G11 plants, increased the average percentage of the G11 generation to $16 \%$. The mean rate over all the generations (G8 to G11) was $18 \%$ (S.E. = 0.9), but four plants presented a significantly higher transgene transmission rate.

Gene silencing, hemizygote instability and chromosomal alteration could contribute to unstable inheritance. Many chromosomal anomalies have been previously demonstrated in Brassica hybrids (Baranger et al., 1995; Benabdelmouna et al., 2003; Chèvre et al., 1998, 1999; Guéritaine et al., 2002). Introgressed chromosomes are very unstable in the absence of a homologous chromosome with which to pair at meiosis. If the bar transgene was located on a chromosome on the oilseed rape genome that rarely recombines with the wild radish genome (Baranger et al., 1997), only plants retaining this chromosome will be resistant. This supernumerary chromosome would be retained in the population in the presence of herbicide selection, but it would be inherited in a non-Mendelian fashion. As wild radish is an obligate outbreeder and flies were used to achieve random cross-pollination among sib-crosses, and assuming that the frequency $p$ of gametes carrying the dominant transgene was the same in pollen and ovule (Guéritaine et al., 2002), panmixia was expected at each generation. Therefore, the frequency of resistant plants should be $p^{2}+2 p(1-p)$. Using the average value of $18 \%$, then $p=0.095$, that is $9.5 \%$ of gametes carrying the transgene, which is consistent with the previous results obtained for the backcrossed BC5 and BC6 generations (Chèvre et al., 1999; Guéritaine et al., 2002). Thus, herbicide-resistant disomic plants $(2 n=18+2)$ are 
Transgene inheritance in wild radish

Table 2. Chromosome counts in wild populations of wild radish and glufosinate-resistant and susceptible plants of generation G9. Resistant G9 plants were sub-divided into two groups according to a hierarchical clustering (see Fig. 1).

\begin{tabular}{lccccccc}
\hline \hline Phenotype & $\begin{array}{l}\text { No. of } \\
\text { plants }\end{array}$ & No. of & & \multicolumn{3}{c}{ Metaphase scores (\%) } \\
& cells & $2 n=16$ & $2 n=17$ & $2 n=18$ & $2 n=19$ & $2 n=20$ \\
\hline Wild populations & 227 & 1295 & 0.5 & 16.5 & 70.7 & 10.2 & 2.1 \\
\hline G9 susceptible & 33 & 198 & 0 & 10.6 & 77.3 & 12.1 & 0 \\
\hline G9 resistant & 32 & 230 & 6.1 & 21.3 & 31.8 & 24.3 & 16.5 \\
group 1 & 22 & 186 & 7.5 & 25.3 & 39.2 & 23.7 & 4.3 \\
group 2 & 10 & 44 & 0 & 4.5 & 0 & 27.3 & 68.2 \\
\hline
\end{tabular}

expected to occur at a calculated frequency of nearly $1 \%$ $\left(100 p^{2}\right)$, while a further $17 \%$ of plants $(200 p(1-p))$ will be resistant due to the presence of one supernumerary chromosome $(2 n=18+1)$, and $82 \%\left(100(1-p)^{2}\right)$ will be susceptible $(2 n=18)$. Among the 86 families studied at random from the $18 \%$ resistant plants, we indeed observed four plants exhibiting a high resistance ratio in their offspring, which was not different from 1 out of $18\left(\chi^{2}=\right.$ 0.14 , NS at $P=0.05,1 \mathrm{df})$. However, these four putative disomic plants were not yet stabilized.

\section{Chromosome counts}

Metaphase chromosome counts of susceptible G9 plants analyzed before herbicide treatment showed some variability of chromosome numbers about the expected value $2 n=18$ (Tab. 2). However, this was not different from wild populations collected from Britain, Burgundy (France) and California (USA) $\left(\chi^{2}=5.4, \mathrm{NS}\right.$ at $P=0.05$, $2 \mathrm{df}$ ). Counts of $2 n=16,17,19$ and 20 could be due to chromosome aggregates and satellite disarticulation which result in an apparently lower or higher number of chromosomes. Two plants had a majority of cell counts of $2 n=19$ and 20, but two such plants were also observed in the wild populations, indicating that a few wild radish plants can be naturally aneuploid. Herbicide-resistant G9 plants in comparison to susceptible G9 plants $\left(\chi^{2}=66.9\right.$, significant at $P=0.05,4 \mathrm{df})$ had a higher number of counts different from $2 n=18$ and, on average, a higher chromosome number (Tab. 2). Hierarchical clustering using Euclidian distances of similarity between plants separated two groups of progeny within the resistant G9 (Fig. 1). The first resistant G9 group (22 of the 32 plants) could be considered normal, with a mean value of 17.9 chromosomes, but showing a high variability of $2 n$ numbers (Tab. 2). The second resistant group (10 plants) had cell counts of 20 chromosomes in the majority of cases. This group also had chromosome counts distributed differently than those of the first group $\left(\chi^{2}=115.4\right.$, significant at $\left.P=0.05,4 \mathrm{df}\right)$. These 10 plants presumably carried a supernumerary chromosome from oilseed rape that contained the herbicide resistance transgene.

It is doubtful that the plants of the first group, considered normal at $2 n=18$, had stably introgressed the transgene, since their progeny were not segregating in a Mendelian fashion. One possible explanation for the apparently normal chromosome number is loss of wild radish chromosomes (e.g. $2 n=17+1)$ as was previously discussed in the case of the $\mathrm{BC} 1$ generation (Benabdelmouna et al., 2003). This could in turn explain high disturbance in chromosome behavior and high chromosome number variability. Given the lack of a plant line that has the normal chromosome number for wild radish and which segregates for herbicide resistance in a Mendelian fashion, it is likely that the bar transgene is located at a site in the oilseed rape genome that recombines with the wild radish genome at very low frequencies (Chèvre et al., 1997b). Stable introgressions are notoriously difficult to achieve between oilseed rape and radish: it required repeated backcrossing and intense selection, both phenotypically and cytologically, to establish stable breeding oilseed rape lines carrying radish genes (Giancolla et al., 2003; Voss et al., 2000).

Even under the strong selection pressure of repeated glufosinate use, which may occur under some field conditions, the majority of the seeds produced by these hybrids are susceptible in each generation. Regardless of significant chromosome disorders and apparent lack of stabilized introgression, the transgene for herbicide resistance can be maintained for a very long time in populations submitted to herbicide selection pressures. However, the prospect of stable introgression of herbicide resistance to wild radish in nature seems remote. Where selection is not present or occurs infrequently, cytogenetic disorders resulting in weak growth, low fitness under competition in the field (Benabdelmouna et al., 2003; Guéritaine et al., 2002, 


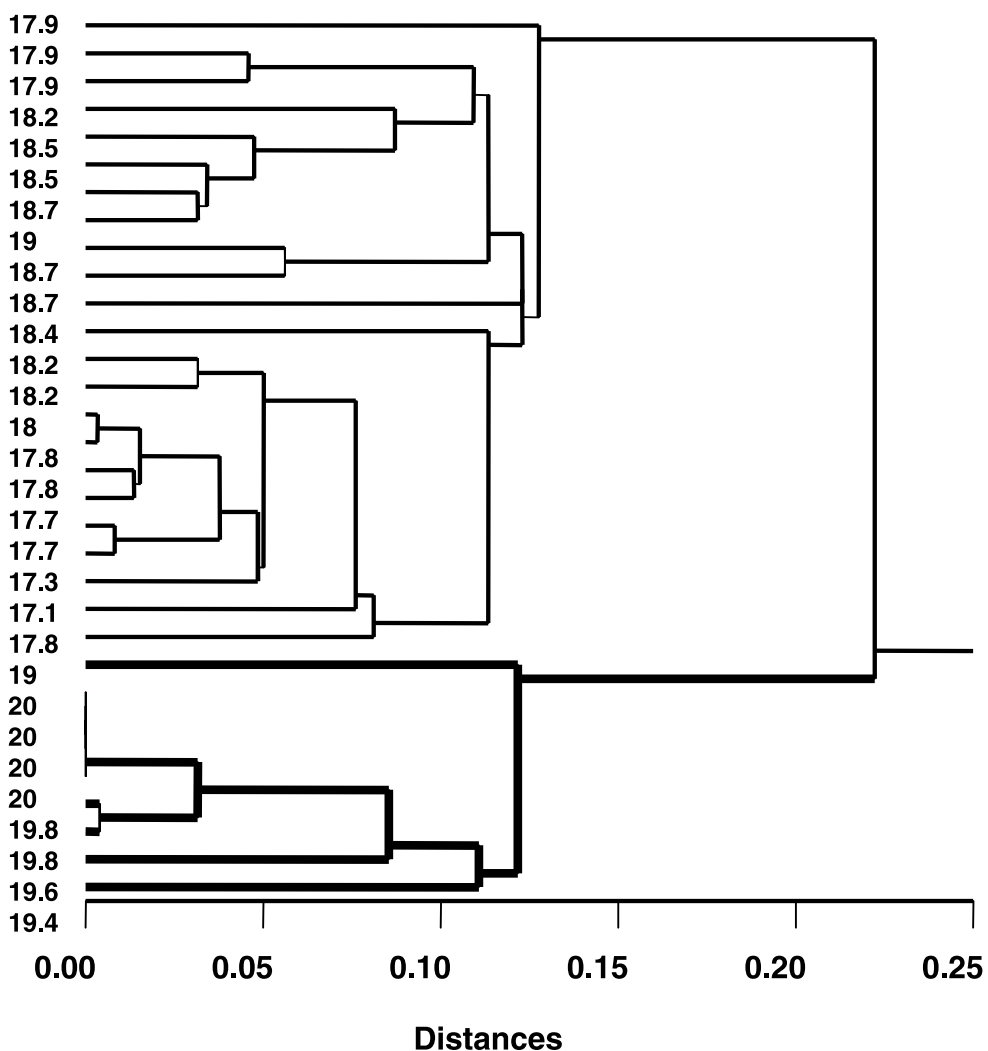

Figure 1. Dendrogram of 32 resistant G9 plants separated into two groups according to Pearson correlation coefficient among chromosome number classes. Group 2 is indicated by bold lines. Numbers are mean number of chromosomes of each plant.
2003) and non-Mendelian inheritance are expected to decrease the frequency of the transgene very rapidly in wild populations of wild radish.

\section{MATERIALS AND METHODS}

\section{Origin of resistant plants}

A fifth generation transgenic line of oilseed rape derived from the Westar cultivar (from Bayer Crop Science, formerly Plant Genetics System, Gand), with resistance to the herbicide glufosinate conferred by the bar gene (Baranger et al., 1997; De Block et al, 1989), was initially crossed with wild radish as the pollen donor at INRA, Rennes (Baranger et al., 1995). Hybrids and resistant hybrid offspring, selected after herbicide spray, were used as females in backcrosses with wild radish over five generations. The fertility of hybrid descendants was progressively restored (Chèvre et al., 1997a), and their chromosome complement tended to be close to that of natural wild radish (Chèvre et al., 1997a, 1998, 1999). At the sixth generation, backcrossed plants (BC6) were obtained in a reciprocal cross, i.e. wild radish plants pollinated by BC5 resistant plants. Resistant and susceptible BC6 plants produced seeds of the seventh generation (G7) under open pollination in the garden without herbicide selection (Guéritaine et al., 2002). Twenty G7 families were taken at random, and G7 seedlings were sprayed in a greenhouse with the herbicide glufosinate (Liberty ${ }^{\circledR}, 3 \mathrm{~g}$ glufosinate $\mathrm{1}^{-1}$ ). One resistant plant of each family was left to flower in a cage containing house-flies to allow random crosspollination, because wild radish is an obligate outbreeder. Seeds from these open-pollinated sib-crosses (G8) were harvested separately on each plant. The frequency of resistant seedlings in the subsequent generations G8 to G11 was assessed in the same way as for the G7 generation, and was evaluated for 50 to 200 seedlings per plant. Families with less than 30 seedlings were not used in calculation. In addition, 21 plants from a G10 family that showed high frequency of resistant descendants $(43 \%)$ were placed in a separate cage and they produced G11bis families. 


\section{Chromosome counts}

Chromosome counts were carried out on the somatic metaphase stage of root-tips of G9 seedlings, and of wild populations of wild radish obtained as seed from Britain, Burgundy (France) and California (USA). Dehulled seeds were germinated in Petri dishes on moist paper (Media Filtrant Durieux, France) at $25{ }^{\circ} \mathrm{C}$ in the dark. Root-tips of 2-3 cm long roots were treated in saturated aqueous $\alpha$-bromonaphthalene solution for $24 \mathrm{~h}$ at $4{ }^{\circ} \mathrm{C}$. The remaining parts of the seedlings were transplanted in the greenhouse. After rinsing and storage for a minimum of $24 \mathrm{~h}$ in acetic-alcohol (1:3), root-tips were digested in a solution containing $0.2 \%$ pectinase and $4 \%$ cellulase Onuzaka $\mathrm{YC}$ for $1.5 \mathrm{~h}$ at $37^{\circ} \mathrm{C}$, then macerated in $5 \mathrm{~N}$ hydrochloric acid for 15 min, and finally stained in Feulgen solution. Chromosome counts were carried out at a magnification of X 1500 (Wild microscope). Resistant G9 plants were clustered on the basis of their chromosome number classes according to a hierarchical clustering procedure using Euclidian distances of similarity between plants (1- Pearson correlation coefficient among chromosome number classes) using SYSTAT software (2000).

\section{ACKNOWLEDGMENTS}

The authors thank Bayer Crop Science for the transgenic material, A.M. Chèvre for providing the backcrossed plants, A. Fleury for assistance, A.M. Chèvre, L. Hall and J. Christianson for helpful comments. This work was supported in part by grants from the Burgundy Region Council and the French Ministry of Agriculture. Prof. A. Al Mouemar had a grant from the Syrian Ministry of Education and Science.

Received December 6, 2004; accepted March 17, 2005.

\section{REFERENCES}

Baranger A, Chèvre AM, Eber F, Renard M (1995) Effect of oilseed rape genotype on the spontaneous hybridization rate with a weedy species: an assessment of transgene dispersal. Theor. Appl. Genet. 91: 956-963

Baranger A, Delourme R, Foisset N, Barret P, Dupuy P, Renard M, Chèvre AM (1997) Wide mapping of a T-DNA insertion site in oilseed rape using Bulk Segregant Analysis and comparative mapping. Plant Breed. 116: 553-560

Benabdelmouna A, Guéritaine G, Abirached-Darmency M, Darmency H (2003) Genome discrimination in progeny of interspecific hybrids between Brassica napus and Raphanus raphanistrum. Genome 46: 469-472

Chèvre AM, Eber F, Baranger A, Renard M (1997a) Gene flow from transgenic crops. Nature 389: 924

Chèvre AM, Eber F, Renard M, Darmency H (1999) Gene flow from oilseed rape to weeds. In Gene flow and agriculture: relevance for transgenic crops, B.C.P.C. Symp. Proc. $N^{\circ}$ 72, Lutman P Ed., Farnham, UK, pp 125-130

Chèvre AM, Eber F, Barret P, Dupuy P, Brace J (1997b) Identification of the different Brassica nigra chromosomes from both sets of $B$. oleracea- $B$. nigra and $B$. napus- $B$. nigra addition lines with a special emphasis on chromosome transmission and self-incompatibility. Theor. Appl. Genet. 94: 603-611

Chèvre AM, Eber F, Baranger A, Hureau G, Barret P, Picault H, Renard M (1998) Characterization of backcross generations obtained under field conditions from oilseed rape-wild radish $\mathrm{F} 1$ interspecific hybrids: an assessment of transgene dispersal. Theor. Appl. Genet. 97: 90-98

Chèvre AM, Eber F, Darmency $\mathrm{H}$, Fleury A, Picault $\mathrm{H}$, Letanneur JC, Renard M (2000) Assessment of interspecific hybridization between transgenic oilseed rape and wild radish under agronomic conditions. Theor. Appl. Genet. 100: 1233-1239

Darmency H, Lefol E, Fleury A (1998) Spontaneous hybridizations between oilseed rape and wild radish. Mol. Ecol. 7: 1467-1473

De Block M, De Brouwer D, Tennig P (1989) Transformation of Brassica napus and Brassica oleracea using Agrobacterium tumefaciens and the expression of the bar and neo genes in the transgenic plants. Plant Physiol. 91: 694-701

Eber F, Chèvre AM, Baranger A., Vallée P, Tanguy X, Renard M (1994) Spontaneous hybridization between a male-sterile oilseed rape and two weeds. Theor. Appl. Genet. 88: $362-368$

Ellstrand NC, Prentice HC, Hancock JF (1999) Gene flow and introgression from domesticated plants into their wild relatives. Annu. Rev. Ecol. Syst. 30: 539-563

Giancola S, Marhadour S, Desloire S, Clouet V, FalentinGuyomarc'h H, Laloui W, Falentin C, Pelletier G, Renard M, Bendahmane A, Delourme R, Budar F (2003) Characterization of a radish introgression carrying the Ogura fertility restorer gene $R f o$ in rapeseed, using the Arabidopsis genome sequence and radish genetic mapping. Theor. Appl. Genet. 107: 1442-1451

Guéritaine G, Bazot S, Darmency H (2003) Emergence and growth of hybrids between Brassica napus and Raphanus raphanistrum. New Phytol. 158: 561-567

Guéritaine G, Sester M, Eber F, Chèvre AM, Darmency H (2002) Fitness of backcross six of hybrids between transgenic oilseed rape (Brassica napus) and wild radish (Raphanus raphanistrum). Mol. Ecol. 11: 1419-1426

Rieger MA, Potter TD, Preston C, Powles SB (2001) Hybridization between Brassica napus L. and Raphanus 
raphanistrum L. under agronomic field conditions. Theor. Appl. Genet. 103: 555-560

Stewart CN, Halfhill MD, Warwick SI (2003) Transgene introgression from genetically modified crops to their wild relatives. Nature Rev. Genet. 4: 806-817

SYSTAT (2000) version 10, SPSS Inc., Chicago

Voss A, Snowdon RJ, Lühs W, Friedt W (2000) Intergeneric transfer of nematode resistance from Raphanus sativus into the Brassica napus genome. Acta Hort. 539: 129134

Warwick SI, Simard MJ, Légère A, Beckie HJ, Braun L, Zhu B, Mason P, Séguin-Swartz G, Stewart CN (2003) Hybridization between transgenic Brassica napus L. and its wild relatives: Brassica rapa L., Raphanus raphanistrum L., Sinapis arvensis L., and Erucastrum gallicum (Willd.) O.E. Schulz. Theor. Appl. Genet. 107: 528-539 